九州大学学術情報リポジトリ

Kyushu University Institutional Repository

\title{
Analysis of Economic Efficiency on Production of Wood Pellet in Korea
}

Kang, Hag Mo

Department of Forest Environmental Science, Chonbuk National University

Choi, Soo Im

Department of Forest Resources, Sunchon National University

Ryu, Jae Yun

National Forestry Cooperative Federation

Lee, Chong Kyu

Department of Forest Resources, Gyeongnam National University of Science and Technology

他

https://doi.org/10.5109/26178

出版情報: 九州大学大学院農学研究院紀要. 58 (1)，pp.175-181，2013-02. Faculty of Agriculture， Kyushu University

バージョン :

権利関係 : 


\title{
Analysis of Economic Efficiency on Production of Wood Pellet in Korea
}

\author{
Hag Mo KANG ${ }^{1}$, Soo Im CHOI ${ }^{*}$, Jae Yun RYU ${ }^{3}$, Chong Kyu LEE ${ }^{4}$ \\ and Noriko SATO
}

Laboratory of Forest Policy, Division of Forest Environment and Management Sciences, Department of Agro-environmental Sciences, Faculty of Agriculture, Kyushu University, Fukuoka 812-8581, Japan

(Received October 26, 2012 and accepted November 8, 2012)

\begin{abstract}
This study intended to seek measures to enhance competitive power and reduce production cost of Korean wood pellet industry through analysis of wood pellet manufacturing cost. For this, the manufacturing cost, total amount of material cost, labor cost, and other expenses occurred in manufacturing process, was analyzed and sensitivity analysis was conducted to understand change of the manufacturing cost depending on material use pattern change and output increase. As the results, it was analyzed that a factor giving the largest effect to the manufacturing cost of wood pellet was material cost and output. Especially, for the material cost, it was identified as more efficient method to reduce the manufacturing cost to produce wood pellet by mixing lumbering byproducts (sawdust) and forest management products (lumbers) in appropriate ratio rather than to use only lumbering byproducts or forest management products. In addition, because material cost per ton is calculated by dividing labor cost and expenses by output, it was identified as a measure to save the manufacturing cost to maintain output corresponding to production capacity of the manufacturer.
\end{abstract}

Key words: wood pellet, manufacturing cost, raw material, output, sensitivity analysis

\section{INTRODUCTION}

Recently, in order to encounter national energy security and climate change according to high oil prices and Convention on Climate Change, "Low Carbon Green Growth" is promoted as government wide policy and Korea has a plan to expand development and supply of self-supportable new \& renewable energy resource strategically. In the National Energy Plan, it is planned to expand new renewable energy supply rate up to $11 \%$ and allocate $31 \%$ of this energy to bio energy (Ministry for Food, Agriculture, Forestry, and Fisheries, 2008).

In development and supply of new \& renewable energy, the wood pellet, a forest biomass, is evaluated as possible to create visible outcome in early stage and having relatively high contribution level in mid and long term. IPCC recommends to substitute bio energy for fossil fuel, assessing that among the alternatives of climate change, the forest had higher flexibility and cost effectiveness (Forest Service, 2010). Wood pellet is recognized as an effective alternative for substituting fossil fuel and reducing greenhouse gas and authorized as a carbon neutral alternative energy with no carbon emission in the Convention on Climate Change (Forest Service, 2009).

Accordingly, Forest Service plans to substitute wood

\footnotetext{
1 Department of Forest Environmental Science, Chonbuk National University, Chonju, 561-756, Korea

2 Department of Forest Resources, Sunchon National University, Suncheon, 540-950, Korea

3 National Forestry Cooperative Federation, Seoul, 138-180, Korea

${ }^{4}$ Department of Forest Resources, Gyeongnam National University of Science and Technology, Jinju, 660-758, Korea

* Corresponding author (E-mail: sooim@sunchon.ac.kr)

* This paper was supported by, in part, Sunchon National University Research Fund in 2012
}

pellet for heating of 140,000 farm houses and 37\% of controlled horticulture by 2020 and produce and supply 1 million ton of wood pellet using domestic materials through expansion of forest management product collection by establishing wood pellet energy utilization measures and domestic demand of the wood pellet is expected to increase continuously (Forest Service, 2010).

Additionally, with Renewable Portfolio Standards (RPS) since 2012, it is prospected that future expansion of new renewable energy market will bring increase of demand on wood pellet. Although traditional new renewable energy market focused on solar and wind power, it is prospected that due to introduction of the RPS, new and renewable energy sources with higher RECs (Renewable Energy Certificates) weight, unit price competitive power, facility scalability and electric power generation efficiency will be selected (Korea Environment Institute, 2011). According to Samsung Economic Research Institute, it is expected that when evaluating with 2 axes of RECs weight and power generation efficiency and facility capacity, the market in marine wind power, tidal power, lignocelluloses biomass single firing power generation will be expanded (Samsung Economic Research Institute, 2011).

Like this, while the demand of wood pellet is forecasted to continue to increase due to its supply expansion policy and related systems, it is actually difficult to expand and industrialize the supply of wood pellet without security of economical efficiency in its production.

Besides for wood pellet related socioeconomic previous studies, Korea Forest Policy Research Association (2003) executed studies on economic efficiency, environmentality, and convenience of heating boiler system and the Ministry of Agriculture and Forestry (2005) conducted economic analysis on thermal energy production 
using forest land waste materials, but the subjects were restricted to wood chips. In addition, in the Ministry of Knowledge and Economy (2008) a study on use of lignocelluloses biomass energy using pitch pine (Pinus rigida) was performed.

Then with announcement of national vision and policy "Low Carbon and Green Growth" by the president Lee Myung Bak in August, 2008, the importance of wood pellet rose as an effective alternative for fossil fuel substitution and greenhouse gas reduction and some of studies on wood pellet production using forest management product and forest management product collection expenses were executed (Korea Forest Research Institute, 2009). And centering on Korea Forest Research Institute, other several studies were also performed including wood pellet available resource search, wood pellet boiler development, quality comparison of wood pellet, and analysis on production, import, and distribution structure of wood pellet. Moreover, Korea Association of Pellet (2010) analyzed actual and potential state of demand and supply of domestic wood pellet as a research service project of Forest Service and presented brief political direction for wood pellet through short, mid and long term prediction.

However, although in the above previous studies, some studies on raw material collection and production cost of wood pellet were performed, there was no or insufficient economic efficiency analysis study on pellet production using lumbering byproducts and forest manage- ment products, main raw materials of wood pellet.

Therefore, this study intends to seek measures to raise competitive power and reduce production cost of future wood pellet industry through analysis on production cost and economic efficiency of pellet production.

\section{MATERIALS AND METHODS}

In order to analyze manufacturing cost and economic efficiency of wood pellet production, field work was performed against 10 domestic manufacturers producing wood pellet with public support and private investment (7 public support manufacturers and 3 private investment manufacturers) from June 15, 2012 to July 30, 2012.

However, among them only 5 manufacturers provided data necessary for analysis to accomplish the purpose of this study actively. Especially, the private investment manufacturers were very negative and passive to data supply. Thus, the analysis of manufacturing cost and economic efficiency of wood pellet production was conducted against the above 5 manufacturers.

As analysis tools, the manufacturing cost calculation items including raw material cost (lumbering byproduct and forest management products), wood pellet output per unit, labor cost, depreciation charge, and expenses were used for analysis of total manufacturing cost.

In addition, sensitivity analysis presuming 2 environmental changes such as when the mount of raw material used was changed and when the output increased was

Table 1. Actual state of wood pellet manufacturing facility in Korea

\begin{tabular}{|c|c|c|c|c|c|}
\hline Investment & Year & Area & Business Entity & Facility Scale & Production Capacity (ton) \\
\hline \multirow{16}{*}{$\begin{array}{c}\text { Government } \\
\text { Support }\end{array}$} & 2008 & Yeoju & Wood Center & 2 ton/hour & 7,200 \\
\hline & \multirow{4}{*}{2009} & Cheongwon & Shinyoung E\&P & 2 ton/hour & 7,200 \\
\hline & & Gimhae & AJU Recording Development & 2 ton/hour & 7,200 \\
\hline & & Danyang & Forestry Cooperative & 2 ton/hour & 7,200 \\
\hline & & Yangpyeong & Forestry Cooperative & 2 ton/hour & 7,200 \\
\hline & \multirow{8}{*}{2010} & Muju & Muju-gun & 2 ton/hour & 7,200 \\
\hline & & Pohang & Forestry Cooperative & 2 ton/hour & 7,200 \\
\hline & & Taebaek & Chunglim & 1 ton/hour & 3,600 \\
\hline & & Gwoisan & Poonglim & 1 ton/hour & 3,600 \\
\hline & & Yeongi & Forestry Cooperative & 1 ton/hour & 3,600 \\
\hline & & Sancheong & Forestry Cooperative & 1 ton/hour & 3,600 \\
\hline & & Geochang & Gaemyeong Wood & 0.5 ton/hour & 1,800 \\
\hline & & Pocheon & Gyeonggi Ascon & 0.5 ton/hour & 1,800 \\
\hline & \multirow{3}{*}{2011} & Gwangyang & Daehyun Wood & 2 ton/hour & 7,200 \\
\hline & & Hwacheon & Hwacheon-gun & 0.5 ton/hour & 1,800 \\
\hline & & Seoguipo & Forestry Cooperative & 0.5 ton/hour & 1,800 \\
\hline \multirow{4}{*}{$\begin{array}{c}\text { Private } \\
\text { Investment }\end{array}$} & \multirow{2}{*}{2009} & Donghae & Ildo Bio & 1 ton/hour & 3,600 \\
\hline & & Hwasun & SK Forestry & 2 ton/hour & 7,200 \\
\hline & \multirow{2}{*}{2010} & Pyeongtaek & Green Eco & 12,500 & 7,200 \\
\hline & & Jeongsun & Wooju Green & 12,500 & 7,200 \\
\hline
\end{tabular}


conducted to review effect of change of manner to use raw material and change of output on the manufacturing cost of wood pellet

\section{RESULTS AND DISCUSSIONS}

\section{Actual state of domestic wood pellet industry}

In the commemorative speech of $60^{\text {th }}$ Anniversary National Foundation on August 15, 2008, the President Lee Myung-Bak presented "Low Carbon Green Growth" as national vision of future 60 years. In order to support the low carbon green growth, the government established and is promoting National Energy Plan to expand the supply ratio of new renewable energy to $11 \%$ by 2030 and as a part of this, development and supply of wood pellet, a forest biomass became spotlighted in forestry.

According to this, the first commercial producer of wood pellet started to operate in wood centers of National Forestry Cooperative Federation by a government support project in 2008 and then, SK Forest initiated production of wood pellet as the first private investment. Total 16 manufacturers including 4 manufacturers in 2009, 8 manufacturers in 2010, and 3 manufacturers in 2011 came to have wood pellet manufacturing facilities by the government support projects. And investment by private capital got accomplished also and total 3 manufacturers including 1 in 2009 and 2 in 2010 started to produce wood pellet. Thus as of 2012, total 20 firms was established and being operated as the wood pellet manufacturing facility in Korea (Table 1). At present, the production amount of domestic wood pellet is presumes as 104,400 tons a year from the facility scale (ton/hour), but for the construction of wood pellet manufacturing facility, usually about 1 year is required from licensing, to earth-ramming, construction, manufacturing facility, purchase of molding machine, subsidiary construction, and test run of the pellet production line. Therefore, the actual production scale is expected to be much lower than 100,000 tons.

In addition, domestic wood pellet consumption market shows a sharp increase, about 200\% every year as 18,216 ton in $2009,33,751$ ton in 2010, and 64,013 in 2011. Among them, domestic wood pellet output supplies about $50 \%$ of total consumption and is in increase trend as 8,527 ton in 2009, 13,008 ton in 2010, and 34,335 ton in 2011 (Han Gyu-Seong, 2012). It is expected that the scale of consumption market increase continuously from increase of demand on wood pellet energy application due to future development and supply of new renewable energy.

\section{Manufacturing cost analysis of wood pellet} General status of wood pellet manufacturers

Investment pattern of the 5 subject wood pellet manufacturers was government support. Generally, the cost to install wood pellet manufacturing facility is different according to production scale per hour and 2.5 billion for 2 ton/hr, 1.75 billion won for 1 ton/hr, and 1 billion won for $0.5 \mathrm{ton} / \mathrm{hr}$ is required. Government support for these installation cost is provided after public subscription product for support of wood pellet manufacturing facility, which consists of $50 \%$ of the national treasury, $20 \%$ of local finance, and $30 \%$ of self load.

As wood pellet manufacturing facility, 1 manufacturer in 2008, 1 manufacturer in 2009, and 3 manufacturers in 2010 came to be equipped with their manufacturing facilities and their production scale was surveyed as 2 ton/hr (production capacity 7,200ton/yr) in 3 manufacturers and 1 ton/hr (production capacity 3,600 ton/yr) in 2 manufacturers. As results of survey on monthly average actual output, it was found that A company that started commercial production of wood pellet at the first in Korea in 2008 produced the most as 671 ton, followed by 460 ton of B company, 450 ton of C company, 202 ton of D company, and 100 ton of E company (Table 2). Particularly, the extremely small output of C and D company for their production capacity were associated with test run of their wood pellet manufacturing facility and production line. In order words, because it is usually required for 1 year to construct a wood pellet manufacturing facility from licensing, to earth-ramming, construction, manufacturing facility, purchase of molding machine, subsidiary construction, and test run of the pellet production line, it is known that about 18 months are required for full scale of production. Therefore, even though a company receives government support in this

Table 2. General status of wood pellet manufacturers

\begin{tabular}{|c|c|c|c|c|c|}
\hline Classification & $\mathrm{A}$ & $\mathrm{B}$ & $\mathrm{C}$ & $\mathrm{D}$ & $\mathrm{E}$ \\
\hline Investment & $\begin{array}{c}\text { Government } \\
\text { Support }\end{array}$ & $\begin{array}{l}\text { Government } \\
\text { Support }\end{array}$ & $\begin{array}{c}\text { Government } \\
\text { Support }\end{array}$ & $\begin{array}{c}\text { Government } \\
\text { Support }\end{array}$ & $\begin{array}{c}\text { Government } \\
\text { Support }\end{array}$ \\
\hline Year of establishment & 2008 & 2009 & 2010 & 2010 & 2010 \\
\hline Facility scale (ton/hr) & 2 & 2 & 1 & 1 & 2 \\
\hline Production capacity (ton) & 7,200 & 7,200 & 3,600 & 3,600 & 7,200 \\
\hline Monthly average production capacity (ton) & 681 & 460 & 450 & 202 & 100 \\
\hline Raw material pattern & $\begin{array}{c}\text { Forest } \\
\text { management } \\
\text { products, } \\
\text { lumbering by } \\
\text { products }\end{array}$ & $\begin{array}{c}\text { Forest } \\
\text { management } \\
\text { products }\end{array}$ & $\begin{array}{c}\text { Forest } \\
\text { management } \\
\text { products }\end{array}$ & $\begin{array}{c}\text { Forest } \\
\text { management } \\
\text { products }\end{array}$ & $\begin{array}{c}\text { Forest } \\
\text { management } \\
\text { products }\end{array}$ \\
\hline
\end{tabular}


year, time difference occurs until entering into full scale operation of production line (Forest Service, 2011)

In addition, the raw material patterns used for production of wood pellet are classified into 2 types generally. The first case is to use lumbering byproduct produced in timberwork, sawdust, and the second case is to use products or pulp wood produced in forest management (Wood Centers of National Forestry Cooperative Federation, 2010)

When investigating raw material use pattern by the wood pellet manufacturers, it was found that while a company used mixture of forest management products and lumbering byproducts, other 4 manufacturers used forest management products for producing wood pellet. Especially, it was shown that while C company used only pine, a needle leaf tree, other manufacturers used mixture of needle leaf trees and broad leaf trees. It is suggested that this is originated on the characteristics of local forest composition.

\section{Estimation of wood pellet manufacturing cost}

Manufacturing cost refers to sum of material cost, labor cost, and expenses generated in manufacturing process (Ministry of Strategy and Finance, 2010). Therefore, wood pellet manufacturing cost means sum of material cost generated in the process of wood pellet manufacturing, which is unit cost required in manufacturing wood pellet with the forest management products (timber) or lumbering byproducts, accompanied labor cost, and expenses (Table 3).

Detailed manufacturing cost of each wood pellet manufacturer is as follows. For material cost, it was found that A company used 70\% of lumbering cost (sawdust) and $30 \%$ of forest management products and other manufacturers used only forest management products. In order to estimate material cost of A company, it is required to estimate the cost required in manufacturing 1 ton of wood pellet using the lumbering byproducts and the forest management products. At first, the cost estimated by applying actual trade price, $20,000 \mathrm{won} / \mathrm{m}^{3}$, to $5.2 \mathrm{~m}^{3}$ of sawdust required for producing 1 ton of wood pellet with lumbering byproducts and multiplying 70\%, the ratio of lumbering byproduct use is 72,800 won/ton. The cost for forest management products, in which 70\% of needle leaf trees and 30\% of broad leaf tress are used in manufacturing wood pellet, is estimated by applying each ratio of material use to each timber price of needle leaf tree and broad leaf tree and multiplying 1.67 ton, the quantity of pulverized saw dust used in producing 1 ton of wood pellet. In other words, the timber price used in manufacturing 1 ton of wood pellet is estimated as \{ (price of needle leaf tree 70,000 won/ton $\times 0.7)+($ broad leaf tree $60,000 \mathrm{won} /$ ton $\times 0.7)\} \times 1.67=111,890 \mathrm{won}$. When applying $30 \%$ to this $(111,890$ won $\times 0.3)$, the ratio of forest management product use, it is calculated as 33,567 won/ton. Therefore, the material cost of A company is $106,367 \mathrm{won} / \mathrm{ton}$, adding the price of lumbering byproducts, $72,800 \mathrm{won} / \mathrm{ton}$, to the price of forest management products, 33,567 won/ton.

The material cost of B, C, D, E company using only the forest management products can be calculated with quantity of raw material input and raw material cost per ton estimated in manufacturing 1 ton of wood pellet. In other words, the material price was estimated by (unit price of timber, raw material cost per ton) $\times$ (input ratio)/ (yield). As the results, it was analyzed that B company required the smallest material cost among 5 manufacturers as 110,750 won/ton for B company, 8,000 won/ton for C company, 100,000 won/ton for D company, and 102,667 won/ton for E company. This is because the forest management products had higher yield as $75 \%$ as well as the lowest price.

The labor cost, which was the wage for labor provided by employees and laborers directly involved in producing wood pellet in the manufacturing field, was estimated by investigating the number of workers and average wage

Table 3. Estimation results of wood pellet manufacturing cost

(Unit: won/ton)

\begin{tabular}{|c|c|c|c|c|c|c|c|}
\hline \multicolumn{3}{|c|}{ Classification } & \multirow{2}{*}{$\begin{array}{c}\text { A } \\
106,367\end{array}$} & \multirow{2}{*}{$\frac{\text { B }}{110,750}$} & \multirow{2}{*}{$\frac{C}{80,000}$} & \multirow{2}{*}{$\frac{\mathrm{D}}{100,000}$} & \multirow{2}{*}{$\begin{array}{c}\mathrm{E} \\
102,667\end{array}$} \\
\hline & Material cost & Direct material cost & & & & & \\
\hline & Labor cost & Direct labor cost & 28,488 & 40,000 & 35,111 & 41,144 & 92,260 \\
\hline & & Depreciation cost & 12,126 & 20,507 & 9,028 & 13,226 & 43,287 \\
\hline & & LPG cost & 26,825 & 43,478 & 21,111 & 63,624 & 25,936 \\
\hline \multirow{5}{*}{$\begin{array}{l}\text { Manufacturing } \\
\text { Cost }\end{array}$} & & Electric power cost & 19,276 & 28,261 & 21,778 & 43,014 & 40,526 \\
\hline & Expenses & Repair cost & 3,412 & 6,522 & 4,889 & 7,296 & 10,000 \\
\hline & & Package and supplies cost & 29,683 & 30,117 & 31,000 & 43,483 & 42,540 \\
\hline & & Other expenses & 11,587 & 10,652 & 27,267 & 17,114 & 16,222 \\
\hline & & Total & 102,909 & 139,537 & 115,073 & 187,713 & 178,511 \\
\hline \multicolumn{3}{|c|}{ General management expenses (9\%) } & 21,399 & 26,126 & 20,717 & 29,597 & 33,609 \\
\hline \multicolumn{3}{|c|}{ Profit (10\%) } & 15,280 & 20,566 & 17,090 & 25,845 & 30,438 \\
\hline \multicolumn{3}{|c|}{ Total manufacturing cost } & 274,442 & 336,979 & 267,990 & 384,299 & 437,485 \\
\hline
\end{tabular}


per person.

Expenses were classified into depreciation cost, LPG cost, electric power cost, repair cost, package and supplies cost and other expenses. For the depreciation cost, straight-line depreciation was applied. In order words it was estimated by applying the number of used years to balance subtracting government support amount from obtained price after grasping all contents of material assets such as pellet machinery, pellet factory, and storage facilities. And the cost required for drying wood pellet, LPG cost and electric power cost, was estimated by applying the amount filled in the survey table by himself. Other expenses include extra-expenses, welfare expenses, insurance, traffic cost, tax and fees, print expenses, and commissions, etc.

In addition, the general cost was estimated by multiplying general management cost rate to the sum of material coast, labor cost and expenses, wherein as the general management cost rate, 9\% applied to "manufacturing and purchasing business of wood and wood products" in manufacturing industry prescribed in "planning criteria of estimated cost of financial regulations 200.04-160-7, 2010.4.15" was applied.

The profit refers to operating profit of manufacturer, which was estimated by applying profit rate $10 \%$ to sum of labor cost, expenses, and general management cost, excluding material cost from the manufacturing cost.

As shown in the above, as results of estimating manufacturing cost required in producing 1 ton, it was identified that A company had the smallest manufacturing cost as 274,442 won, followed by 267,990 won of C company, 336,979 won of B company, and 437,485 won of $\mathrm{E}$ company. The reason that $\mathrm{C}$ company had higher total manufacturing cost in spite of much lower raw material cost of at least 20,000 won/ton than A company with the lowest manufacturing cost was because its average output of wood pellet was only $66 \%$ of A company. In other words, it is suggested that because in the estimation of manufacturing cost per ton, expenses is calculated by diving labor cost and expenses other than material cost by output, output as well as material cost may give a great effect to the manufacturing cost.

\section{Sensitivity analysis}

It is considered that things to give the largest effect to the manufacturing cost of wood pellet is raw material cost, a variable cost inserted into producing 1 ton of wood pellet, rather than invariable costs such as labor cost and expenses and output of wood pellet produced from this.

Thus, sensitivity analysis presuming 2 environmental changes such as when the mount of raw material used was changed and when the output increased was conducted to review effect of change of manner to use raw material and change of output on the manufacturing cost of wood pellet.

Among the 5 manufactures, sensitivity analysis was performed against A company. It was because A company used lumbering byproducts and forest management products as raw materials, so it is possible to understand the effect of manufacturing cost depending on change of raw material use amount. In addition, also for understanding change of manufacturing cost depending on change of output, it was manufacturing wood pellet corresponding to the facility scale ( 2 ton/hr).

In order to perform full scale of wood pellet production corresponding to the facility scale, considerable period for construction of manufacturing facility and test run of pellet production line is required. D and E company are considered not to approach normal in the aspect of output. Although B and C company can be considered to approach normal stage in the aspect of wood pellet out, but they are excluded because their use of raw materials is restricted in the forest management products.

\section{Change of raw material use pattem}

A company, the subject of sensitivity analysis, uses $70 \%$ of lumbering byproducts (sawdust) and 30\% of forest management products (timber) as raw materials. Thus, in order to review the effect of change of raw material use pattern on the manufacturing cost of wood pellet, 4 scenarios were presumed. Thus, in order to review the effect of change of raw material use pattern on the manufacturing cost of wood pellet, 4 scenarios were presumed.

In addition, it was presumed that although the material cost per ton and general management cost were changed in manufacturing wood pellet, invariable costs such as labor cost and expenses were not change. Scenario 1 was the case that use ratio of the lumbering byproducts (saw dust) was 100\%, scenario 2 was the case that use ratio of the forest management products (timber) was $100 \%$, Scenario 3 was the case that the use ratio of the lumbering byproducts (saw dust) versus the forest management products (timber) was 80\%:20\%, and scenario 4 was the case that the use ratio of the lumbering byproducts (saw dust) versus the forest management products (timber) was 90\%:10\%.

As results of sensitivity analysis depending on change of raw material use pattern, it was identified that the

Table 4. Example of material cost estimation of B company using only forest management products

\begin{tabular}{|c|c|c|c|c|}
\hline Classification & Average price per ton & Input ratio & Yield & Unit price \\
\hline Needle-leaf trees & 67,500 won & $70 \%$ & \multirow{2}{*}{$60 \%$} & 78,750 won \\
\hline Broad-leaf trees & 64,000 & $30 \%$ & & 32,000 won \\
\hline \multicolumn{3}{|c|}{ Raw material cost per ton } & & 110,750 won \\
\hline
\end{tabular}

Note: Unit price $=($ average price $\times$ input ratio $) /$ yield 
scenario 3 where the use ratio of the lumbering byproducts (saw dust) versus the forest management products (timber) was 80\%:20\% had the lowest manufacturing cost per ton as 266,359 won/ton, followed by the scenario 4 where the use ratio of the lumbering byproducts (saw dust) versus the forest management products (timber) was $90 \%: 10 \%$ as 269,100 won/ton (Table 5). Comparing 274,442 won, the result of wood pellet manufacturing cost estimation shown in Table 3, it was analyzed that the scenario 3 was $2.9 \%$ lower and the scenario 4 was $1.9 \%$ lower than that. On the contrary, it was identified that the scenario 2 that used only the forest management products (timber) showed the highest manufacturing cost and the scenario 1 using only lumbering byproduct (sawdust) showed the second higher manufacturing cost.

Therefore, it seems that the measure to save manufacturing cost is to mix the lumbering byproducts and the forest management products in appropriate ratio rather than using only one of them as raw materials.

\section{Output Change}

A company, the subject of sensitivity analysis, has 2 ton/hr of facility scale and 7200 ton/yr of annual production capacity. Its operation time per day is 24 hours, and it produces monthly average 681 tons of wood pellet. Its operation time per day is 24 hours, and it produces monthly average 681 tons of wood pellet. As explained in the above, as the material cost per ton is calculated by dividing labor cost and expenses by output, output may give a great effect to the manufacturing cost. Therefore, when the output increases further, the manufacturing cost is reduced further. However although the output cannot be increased unlimitedly in terms of wood pellet manufacturing facility size, how much effect it gives to the manufacturing cost in producing 8000, 9,000, 10,000 tons of wood pellet within the range not exceeding 30\% of annual production capacity was reviewed. Provided, it was presumed that the material cost was not changed.

As results of sensitivity analysis depending on output change, it was analyzed that in case of producing 9,000 ton and 10,000 ton a year, the manufacturing cost per ton were $4.8 \%$ lower and $9.5 \%$ lower than 274,442 won, the result of wood pellet manufacturing cost per ton estimation shown in Table 3, as 261,285 won and 248,347 won respectively (Table 6).

\section{CONCLUSION}

This study intended to seek measures to raise competitive power and reduce production cost of future wood pellet industry through analysis on material cost of pellet production.

For analysis of wood pellet manufacturing cost, the manufacturing cost calculation items including raw material cost (lumbering byproduct and forest management

Table 5. Sensitivity analysis results depending on raw material use pattern

(Unit: won/ton)

\begin{tabular}{ccccc}
\hline Classification & Scenario 1 & Scenario 2 & Scenario 3 & Scenario 4 \\
\hline Material cost & 104,000 & 139,667 & 99,012 & 28,488 \\
Labor cost & 28,488 & 28,488 & 101,506 & 102,909 \\
Expenses & 102,909 & 102,909 & 20,737 & 102,909 \\
General management expenses (9\%) & 21,186 & 24,396 & 15,213 & 15,236 \\
Profit (10\%) & 15,258 & 311,038 & 266,359 & 269,100 \\
\hline Total manufacturing cost & 271,841 & &
\end{tabular}

Note: 1 . Scenario 1 is the case that the use ratio of lumbering byproduct (saw dust) is $100 \%$

2. Scenario 2 is the case that the use ratio of forest management product (timber) is $100 \%$

3. Scenario 3 is the case that the use ratio of the lumbering byproducts (saw dust) versus the forest management products (timber) is $80 \%: 20 \%$

4. Scenario 4 is the case that the use ratio of the lumbering byproducts (saw dust) versus the forest management products (timber) is $90 \%: 10 \%$

Table 6. Results of sensitivity analysis depending on output change

(Unit: won/ton)

\begin{tabular}{cccc}
\hline Classification & 8,000 ton & 9,000 ton & 10,000 ton \\
\hline Material cost & 106,367 & 106,367 & 106,367 \\
Labor cost & 29,085 & 25,867 & 23,289 \\
Expenses & 104,815 & 94,557 & 86,344 \\
General management expenses (9\%) & 21,624 & 20,411 & 19,440 \\
Profit (10\%) & 15,552 & 14,083 & 12,907 \\
\hline Total manufacturing cost & 277,443 & 261,285 & 248,347
\end{tabular}


products), wood pellet output per unit, labor cost, depreciation charge, and expenses were used for analysis of total manufacturing cost against 5 wood pellet manufactures. In addition, sensitivity analysis presuming 2 environmental changes such as (1) when the mount of raw material used was changed and (2) when the output increased was conducted to review how much effect the change of raw material use pattern and output gives to the manufacturing cost of wood pellet.

As the results, it was analyzed that the factors giving the largest effect to the manufacturing cost of wood pellet were material cost and output. Especially, it was identified that as the raw material cost might have about 20,000 won of difference depending on characteristics of regions where the manufacturer was located, it gave great effect to the material cost of wood pellet. Additionally, it is suggested that as the material cost per ton is calculated by dividing labor cost and expenses by output, output may give a great effect to the manufacturing cost. In other words, it is considered that when output increases further, the manufacturing cost can be reduced further.

Besides, as results of case study on the effect of raw material pattern and output change on the manufacturing cost of wood pellet, it was identified that it was a measure able to save $2 \sim 3 \%$ of manufacturing cost to use the mixture of the lumbering byproducts and the forest management products in appropriate ratio rather than each of the lumbering byproducts and the forest management products. In addition, it was analyzed that when producing wood pellet exceeding the annual production capacity ( 7,200 ton) by about 30\% (10,000 ton), it was possible to save the manufacturing cost by $9.5 \%$.

Therefore, it is considered that in order to raise competitive power through reduction of wood pellet manufacturing cost in future, the measure to increase output as well as appropriate input of lumbering byproduct shall be preceded rather than single pattern use of raw material.

\section{REFERENCES}

Forest Service. 2009 Climate change and forest

Forest Service. 2010 Report on promotion of wood pellet supply

Forest Service. 2011 Actual state of wood pellet manufacturing facility in Korea

Gyu-Seong Han. 2012 Trend and prospect of pellet market in Korea. Production and application technology of lignocelluloses solid bio-fuel. Korea Forest Research Institute

Korea Association of Pellet. 2010 Research on Wood Pellet Management Based on Prediction of Future Supply and Demand for Wood Pellet

Korea Environment Institute. 2011 Effect of RPS enforcement on activation of renewable energy. Environment Forum 15 (4): $1-8$

Korea Forest Policy Research Association. 2003 Research on economic application of forest management products

Korea Forest Research Institute. 2009 Report of study on characteristics of wood pellet using forest management products. Pending issue

Ministry of Agriculture and Forestry. 2005 Production and Supply System Design of Heating Energy for Vitalization of Environmentally Friendly Forestry

Ministry of Food, Agriculture, Forestry, and Fisheries. 2008 Development strategy of green energy industry (draft) related bio-energy application strategy in agriculture, forestry, and fisheries (draft)

Ministry of Knowledge Economy. 2008 A Study on the Economic Analysis for Utilizing of the Pitch Pine Focusing on Energy Utilizing of Ligneous Biomass -

Ministry of Strategy and Finance. 2010 Planning criteria of estimated cost (financial regulations 2200.04-160-7, 2010.4.15)

Samsung Economic Research Institute. 20112012 Introduction of Renewable Portfolio Standards. SERI Economy Focus 344: 1-14

Wood Center of National Forest Cooperative Federation. 2010 Study on application of domestic wood. 2010 Research product report 